\title{
Spark plasma effect on microstructure and mechanical properties of alumina-nickel-cobalt composite
}

\section{(Efeito da ignição por plasma na microestrutura e propriedades mecânicas do compósito alumina-níquel-cobalto)}

\author{
J. Baseri ${ }^{1 *}$, R. Naghizadeh ${ }^{1}$, H.R. Rezaie ${ }^{1}$, F. Golestanifard ${ }^{1}$ \\ ${ }^{I}$ Iran University of Science and Technology, School of Metallurgy and Materials Engineering, Tehran, Iran
}

\begin{abstract}
Spark plasma sintering (SPS) is an advanced process of sintering materials at low temperatures and short time by creating spark plasma at very high temperatures in the small points and short times, by which materials with high sintering temperature can sinter at lower temperatures. In this study, alumina-nickel-cobalt composites were sintered by SPS and RHP (rapid hot press) methods to investigate the effects of electric pulse on their microstructure and mechanical properties. To this end, sample powders containing alumina, nickel-cobalt aluminate spinel, and aluminum were sintered at $1380{ }^{\circ} \mathrm{C}$ under $30 \mathrm{MPa}$ pressure for 10 min by SPS and RHP and then investigated. The densities of both samples were about $98 \%$ of theoretical density. Also, hardness and fracture toughness of both samples were about $11 \mathrm{GPa}$ and $14 \mathrm{MPa}^{0.5}$, respectively. The bending strengths of the SPS and RHP samples were 380 and $336 \mathrm{MPa}$, respectively.
\end{abstract}

Keywords: spark plasma sintering, rapid hot pressing, alumina-nickel-cobalt composite.

Resumo

A técnica de spark plasma sintering (SPS) é um processo avançado de sinterização de materiais em baixas temperaturas e curto tempo por meio da formação de plasma em temperaturas muito altas em pequenos pontos e curtos tempos, pela qual os materiais de alta temperatura de sinterização podem sinterizar em temperaturas mais baixas. Neste estudo, os compósitos de aluminaníquel-cobalto foram sinterizados pelos métodos SPS e RHP (prensagem a quente rápida) para investigar os efeitos do pulso elétrico em sua microestrutura e propriedades mecânicas. Para este fim, os pós das amostras contendo alumina, espinélio de aluminato de níquel-cobalto e alumínio foram sinterizados a $1380{ }^{\circ} \mathrm{C}$ sob pressão de $30 \mathrm{MPa}$ durante $10 \mathrm{~min}$ por SPS e RHP e depois investigados. As densidades de ambas as amostras foram aproximadamente $98 \%$ da densidade teórica. Além disso, a dureza e tenacidade à fratura de ambas as amostras foram aproximadamente $11 \mathrm{GPa}$ e $14 \mathrm{MPa} . \mathrm{m}^{0,5}$, respectivamente. As resistências à flexão das amostras SPS e RHP foram 380 e 336 MPa, respectivamente.

Palavras-chave: spark plasma sintering, prensagem a quente rápida, compósito de alumina-níquel-cobalto.

\section{INTRODUCTION}

Hot pressing is a well-known method of applying high temperature and uniaxial pressure at the same time, to sinter porous or fully dense components. This technique was established for powder metallurgy and ceramic industry over the last few years. Sintering is done by particle rearrangement and plastic flow at particle interfaces. The driving force for sintering increases by the applied pressure and can lead to decrease grain size and also better mechanical and physical properties. Nowadays, hot pressing is done by three methods, namely, inductive heating, indirect resistance heating, and direct hot pressing (DHP) [1-4]. In inductive heating technology, when the mold is placed under a high-frequency electromagnetic field, heat is produced. Pressure is applied uniaxially or biaxially to the punches. In this approach, the heating and the pressure have no reciprocal impact. On the

*j.baseri@gmail.com other hand, high-frequency generators are expensive, the mold must have high conductivity, and the high heating rate results in a high-temperature difference between the surface and the core of the mold, which can cause damage to the mold. In indirect resistance heating technology, the mold is heated by convection. Graphite elements are heated by electric current and then those heat the mold in the next step. Merits are the feasibility of high temperatures, reciprocate of the conductivity of the mold, heat, and pressure. The most significant demerit is the time-consuming heating [5, 6]. Rapid hot press (RHP) is a low voltage, direct current (DC) activated, pressure-assisted sintering technique. Spark plasma sintering (SPS) is also the same, but in SPS technique, the direct current has pulses. Both SPS and RHP are categorized in field-assisted sintering technique (FAST). The main difference between the last mentioned method and RHP is the way heat is produced and then transferred to the body. If the body is electrically conductive, then heat will be transferred through conductive parts of the pressing 
tool. Otherwise, an electrically conductive tool like graphite sheet must be used. The heat produced by Joule heating and conveyed by conduction to the green body [7-9].

Alumina is one of the most attractive ceramics which is used in industries. Excellent thermal stability, hardness, and refractoriness properties are the merits of alumina, while relatively low fracture toughness and strength are its demerits [10-13]. Nowadays, many studies have focused on improving alumina properties with metal reinforcing particles. Some studies were done on alumina-copper composites [14-16], alumina-silver composites [17, 18], alumina-molybdenum composites [10], alumina-chromium composites [19], alumina-cobalt composites [20], and alumina-nickel composites. Also, due to their high melting temperatures, suitable toughness, and magnetic properties, some metals such as cobalt, nickel, and iron are of interesting research area $[13,21]$. Though, the alumina-metal solid solution is comparatively less investigated. Because of the few studies on the alumina-metal solid solution and alumina-spinel particularly on their mechanical properties, in the present study, alumina (nickel-cobalt) composite was sintered once in direct current (RHP) and again with pulsed direct current (SPS) to study spark plasma effect on microstructure and mechanical properties of alumina-nickel-cobalt composites.

\section{EXPERIMENTAL}

Reactive alumina powder (d50: $2 \mu \mathrm{m}, \mathrm{d} 90: 4 \mu \mathrm{m}$, BET: $1.9 \mathrm{~m}^{2} / \mathrm{g}$, PFR20, Alteo, France), nickel-cobalt aluminate spinel $\left[(\mathrm{Ni}, \mathrm{Co}) \mathrm{Al}_{2} \mathrm{O}_{4}\right]$, and aluminum powder $(1-2 \mu \mathrm{m}$, Germany) were mixed and then ball milled in a high purity polyethylene container using high purity alumina milling balls with diameters varying from 2 to $30 \mathrm{~mm}$ for $4 \mathrm{~h}$. Fig. 1 shows the X-ray diffraction (XRD) pattern and transmission electron microscopy (TEM) image of Ni-Co aluminate spinel powder and scanning electron microscopy (SEM) image of aluminum powder.

The amount of spinel and aluminum were managed to result in $10 \mathrm{vol} \%$ of metal solid solution phase in the final composite. The powder was loaded into a $50 \mathrm{~mm}$ diameter graphite die and was then pressed at $30 \mathrm{MPa}$ and heated at $1380{ }^{\circ} \mathrm{C}$ for $10 \mathrm{~min}$ with a heating rate of $50 \mathrm{~K} / \mathrm{min}$ in an RHP device (KPF, Iran), once with applying spark and once without it. Archimedes method was used to obtain the relative density (ASTM C20). The sintered bodies were cut using a diamond blade and then polished with diamond paste to get a mirror-like surfaces. The final dimensions of these specimens were $3.5 \times 3.5 \times 45 \mathrm{~mm}$. The fracture strength of the specimens was measured by a 3-point bending test using a span of $20 \mathrm{~mm}$ and a crosshead speed of $0.5 \mathrm{~mm} / \mathrm{min}$ (DBBP-500, Bongshin, Korea). The microstructural analysis of the polished specimens was investigated by field emission scanning electron microscopy (FESEM, Mira 3-XMU). The X-ray diffraction patterns of the specimens were accomplished by a diffractometer (X'Pert Pro, Philips, Netherlands) by means of a Cu-target tube $(\lambda=0.15 \mathrm{~nm})$. The patterns were recorded in the $2 \theta 10^{\circ}$ -
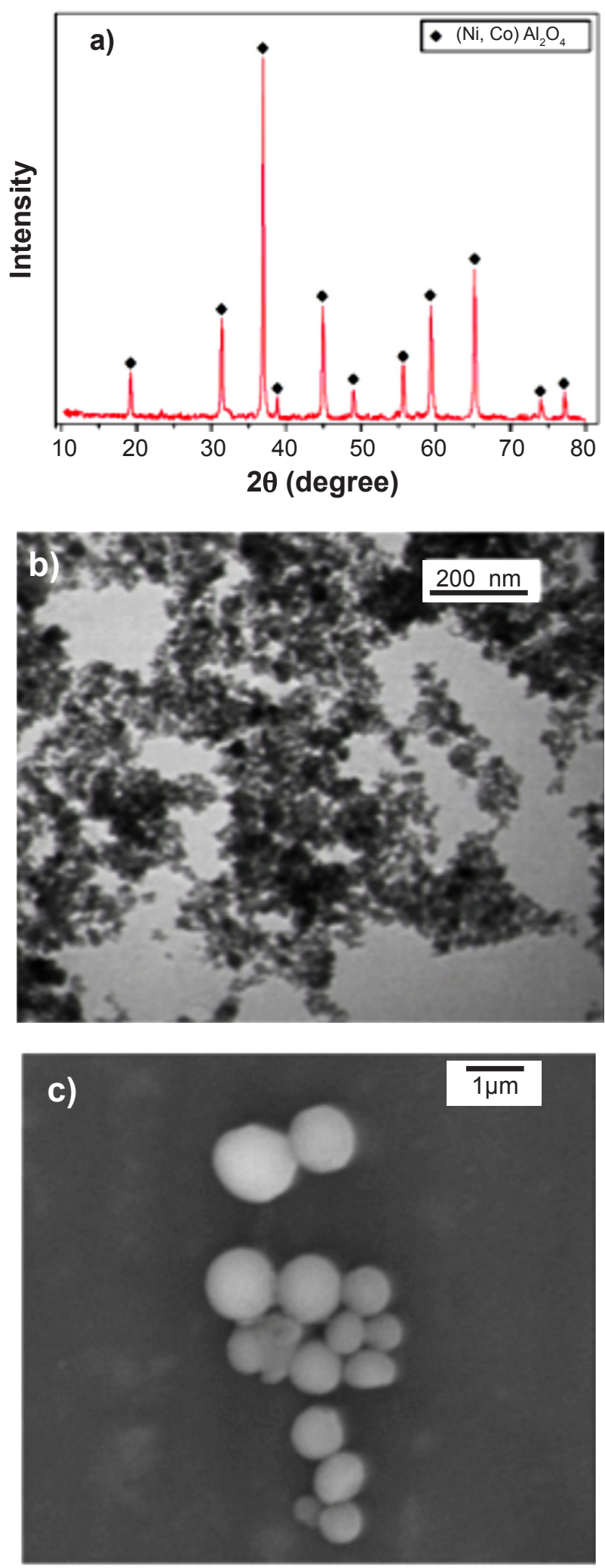

Figure 1: X-ray diffraction pattern and TEM image of Ni-Co aluminate spinel $\left[(\mathrm{Ni}, \mathrm{Co}) \mathrm{Al}_{2} \mathrm{O}_{4}\right]$ and $\mathrm{SEM}$ image of aluminum particles.

[Figura 1: Difratograma de raios $X$ e imagem de microscopia eletrônica de transmissão do espinélio de aluminato de Ni-Co $\left[(\mathrm{Ni}, \mathrm{Co}) \mathrm{Al}_{2} \mathrm{O}_{4}\right]$ e imagem de microscopia eletrônica de varredura (MEV) de partículas de alumínio.] 
$80^{\circ}$ range at room temperature, with a scanning rate of 0.001 ${ }^{\circ} \mathrm{s}^{-1}$ and a step interval of $0.02^{\circ}$. The Vickers microhardness $\left(\mathrm{H}_{\mathrm{v}}\right)$ of the sintered composites was measured on polished surfaces with a load of $10 \mathrm{kgf}$ by means of a hardness tester (V-test II, Bareiss). Fracture toughness $\left(\mathrm{K}_{\mathrm{Ic}}\right)$ was calculated by direct crack measurement method with $10 \mathrm{kgf}$ load and a $100 \mu \mathrm{m} / \mathrm{s}$ crosshead speed, in the same way, using Evans and Charles formula $[22,23]$.

\section{RESULTS AND DISCUSSION}

Fig. 2 shows XRD patterns of the composite before and after RHP and SPS. There was no peak related to spinel or oxide in both patterns. Also, the three peaks $\left(43^{\circ}, 57^{\circ}\right.$ and $76^{\circ}$ ), related to metal solid solution phase, were detected sharply in both patterns. Therefore, sparks did not affect the reduction process. Reduction with aluminum could happen with the following reaction [24]:

$$
3 \mathrm{CoAl}_{2} \mathrm{O}_{4}+2 \mathrm{Al}=3 \mathrm{Co}+4 \mathrm{Al}_{2} \mathrm{O}_{3}
$$

The volume fraction of metal phase calculated from XRD pattern was about $9.8 \%$ and $10.1 \%$ for RHP and SPS method, respectively, which had an excellent agreement with initial calculation [25]. However, sparks had a significant effect on crystallite size calculated by Williamson-Hall method. Crystallite size of metal phase in RHPed sample was about $103 \AA$, while crystallite size of metal phase in the SPSed
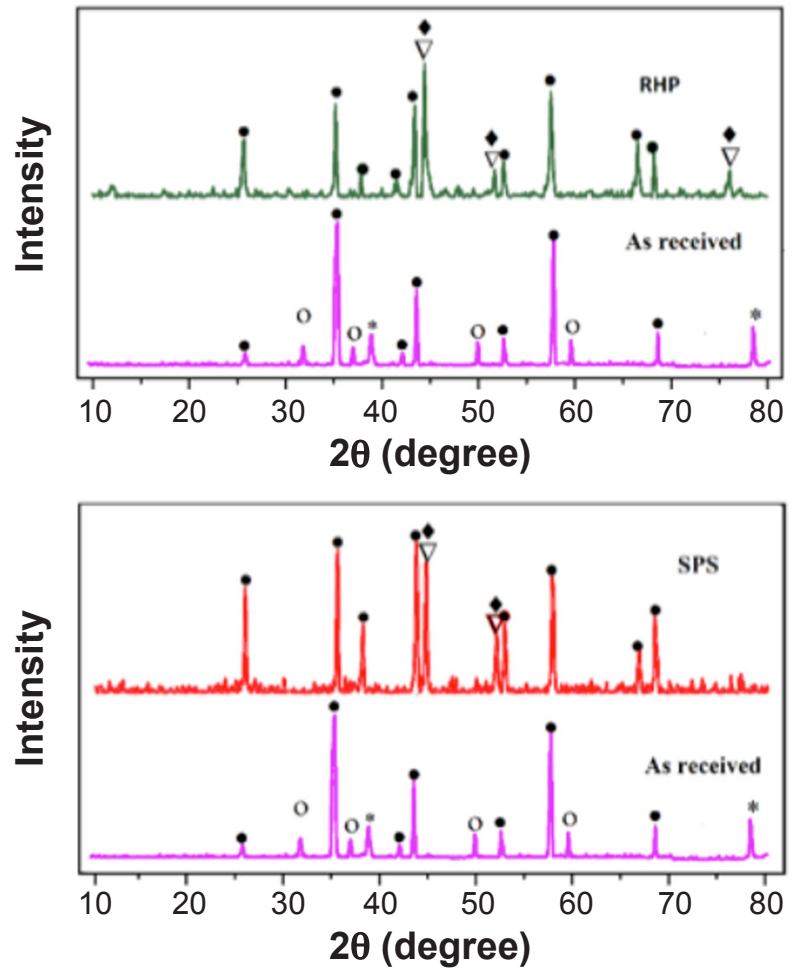

Figure 2: X-ray diffraction patterns of the composite before and after RHP (a) and SPS (b): $\mathrm{O}-(\mathrm{Ni}, \mathrm{Co}) \mathrm{Al}_{2} \mathrm{O}_{4} ; \bullet-\mathrm{Al}_{2} \mathrm{O}_{3}$; $-\mathrm{Ni}$; $\nabla-\mathrm{Co} ; *-\mathrm{Al}$.

[Figura 2: Difratogramas de raios $X$ do compósito antes e depois de RHP (a) e SPS (b).] sample was about less than half of the RHP (42 $\AA$ ). This significant difference could be related to the spark, which produces $2000{ }^{\circ} \mathrm{C}$ for less than a millisecond in a random small area. This condition could prevent crystallite growth or sometimes breaks large crystallite [26-28].

Fig. 3 demonstrates FESEM of the microstructure of the composite sintered by RHP and SPS methods. As it is shown in Fig. 3, metal phase in the SPSed sample was finer and dispersed more homogenously than in RHPed sample. It seems that, because of spark plasma effect, crystallite size and grain size of SPSed sample dwindled in size. Fig. 4 demonstrates the image analysis of FESEM image of the
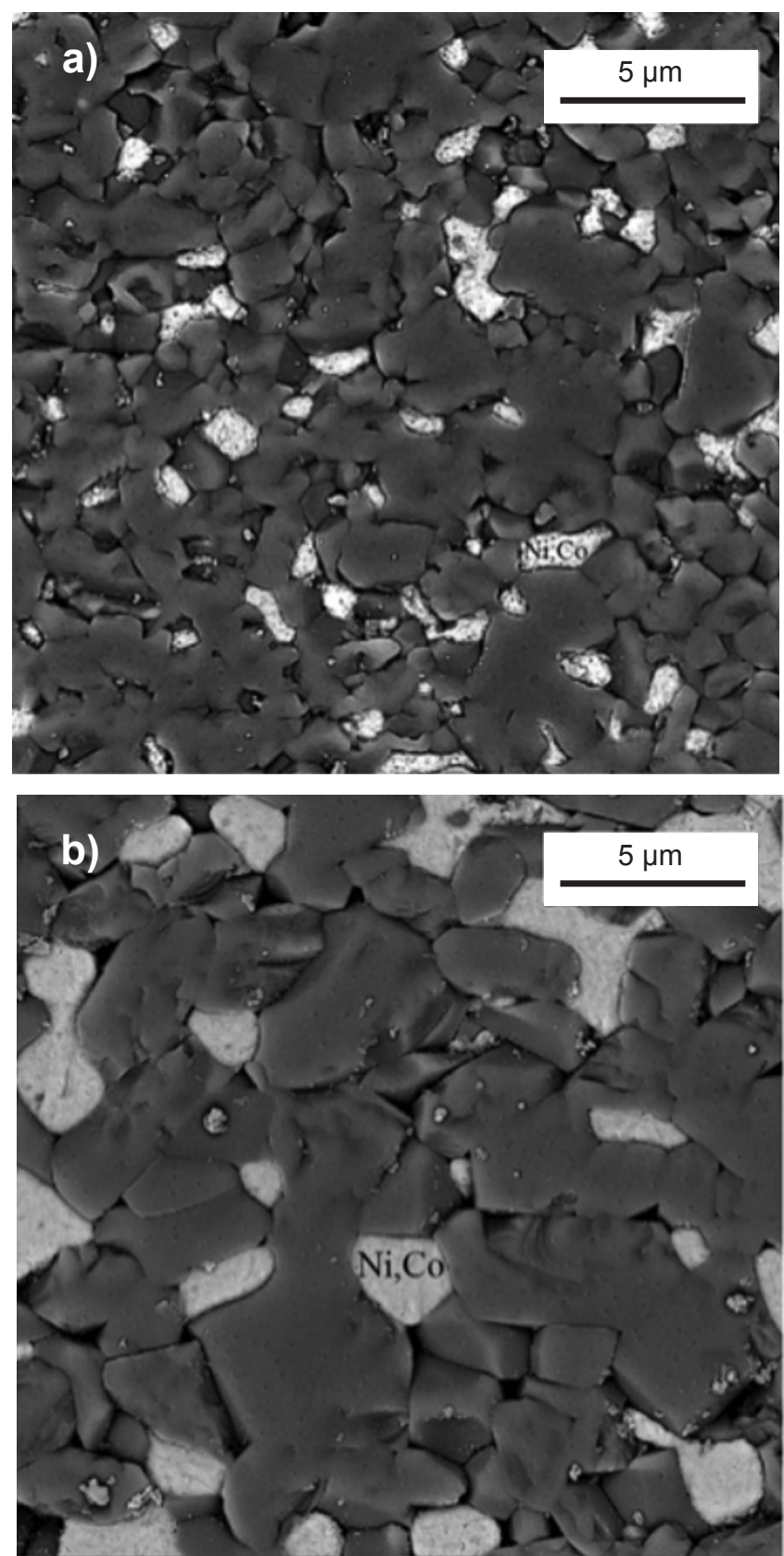

Figure 3: FESEM of the microstructure of the composite sintered by SPS (a) and RHP (b) method.

[Figura 3: Imagens de MEV da microestrutura do compósito sinterizado pelo método SPS (a) e RHP (b).] 
Table I - Mechanical and physical properties of the two samples.

[Tabela I - Propriedades mecânicas e físicas das duas amostras.]

\begin{tabular}{ccccc}
\hline Sample & $\begin{array}{c}\text { Fracture toughness } \\
\left({\mathrm{MPa} . \mathrm{m}^{0.5}}^{0}\right.\end{array}$ & $\begin{array}{c}\text { 3-point bending } \\
\text { strength (MPa) }\end{array}$ & $\begin{array}{c}\text { Hardness } \\
(\mathrm{GPa})\end{array}$ & Relative density (\%) \\
\hline RHP & $11.2 \pm 0.4$ & $336 \pm 3$ & $13.8 \pm 0.5$ & 98.2 \\
SPS & $11.1 \pm 0.6$ & $380 \pm 4$ & $14.6 \pm 0.4$ & 98.4 \\
\hline
\end{tabular}

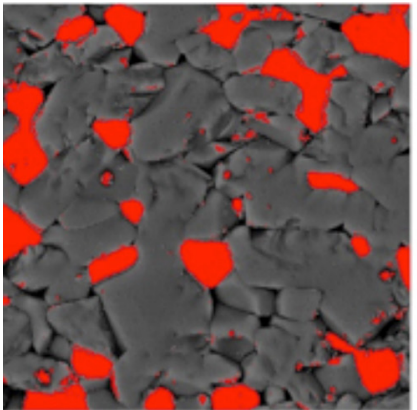

a)

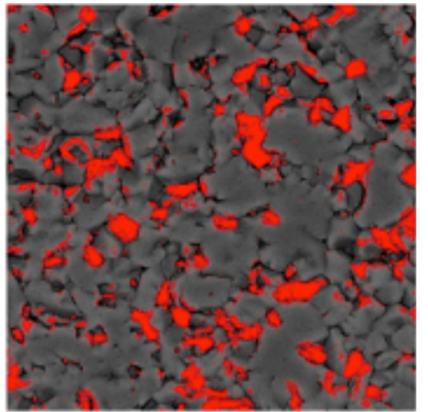

b)
Figure 4: Image analysis of FESEM images of the microstructure of the composite sintered by RHP (a) and SPS (b) method.

[Figura 4: Análise de imagem das micrografias de MEV do compósito sinterizado pelo método RHP (a) e SPS (b).]

microstructure of the composite sintered by RHP and SPS method. This analysis showed that there were about 11.5 vol\% of metal phase in SPS sample and about 10.4 vol\% of metal phase in RHP sample. These results were in good agreement with XRD results and initial calculations.

Table I compares the mechanical and physical properties of the two samples. As can be seen, both samples reached an acceptable relative density of above $98 \%$ of the theoretical density. Also, hardness and fracture toughness of them did not show a significant difference, which can be due to the same material composition of the two samples and moreover the similarity of their relative density. However, according to 3-point bending strength results, the SPS specimen was about $13 \%$ stronger, which can be due to a finer microstructure and furthermore a more homogenous metallic phase dispersion within this sample.

\section{CONCLUSIONS}

The results of this study showed that for the preparation of alumina-cobalt composites, spark plasma sintering (SPS) is a more suitable method than rapid hot pressing (RHP). In both methods, the specimens were heated to $1380{ }^{\circ} \mathrm{C}$ under $30 \mathrm{MPa}$ for $10 \mathrm{~min}$ and reached about $98 \%$ of the theoretical density, $14 \mathrm{GPa}$ in hardness and $11 \mathrm{MPa} \cdot \mathrm{m}^{0.5}$ in fracture toughness. However, SPS method, which generates shortterm and high-temperature sparks by alternating pulses in direct current, could lead to a finer and more homogenous microstructure in comparison to RHP method. Finer and more homogenous microstructure in SPSed sample led to $13 \%$ better bending strength. In another word, a bending strength of $380 \mathrm{MPa}$ for the SPSed sample was compatible with bending strength of $336 \mathrm{MPa}$ for RHP sample.

\section{REFERENCES}

[1] J. Langer, M.J. Hoffmann, O. Guillon, Acta Mater. 57, 18 (2009) 5454.

[2] P. Guyot, G. Antou, N. Pradeilles, A. Weibel, M. Vandenhende, G. Chevallier, A. Peigney, C. Estournès, A. Maître, Scr. Mater. 84-85 (2014) 35.

[3] M. Mazaheri, S.A. Hassanzadeh-Tabrizi, S.K. Sadrnezhaad, Ceram. Int. 35, 3 (2009) 991.

[4] Y. Zhou, K. Hirao, Y. Yamauchi, S. Kanzaki, J. Eur. Ceram. Soc. 24, 12 (2004) 3465.

[5] O. Guillon, J. Gonzalez-Julian, B. Dargatz, T. Kessel, G. Schierning, J. Räthel, M. Herrmann, Adv. Eng. Mater. 16 (2014) 830 .

[6] R.M. German, Sintering: from empirical observations to scientific principles, Elsevier (2014) 387.

[7] G. Tayler, "Apparatus for making hard metal compositions", US1896854 A (1933).

[8] P. Schreyer, Ceram. Forum Int. 86, 4 (2009) E39.

[9] Z.A. Munir, U. Anselmi-Tamburini, M. Ohyanagi, J. Mater. Sci. 41, 3 (2006) 763.

[10] K. Konopka, M.S. Maj, K.J. Kurzydłowski, Mater. Charact. 51, 5 (2003) 335.

[11] M. Liberthal, W.D. Kaplan, Mater. Sci. Eng. A 302 (2001) 83 .

[12] R.Z. Chen, W.H. Tuan, J. Eur. Ceram. Soc. 19 (1999) 463.

[13] N.L. Barham, W.D. Kaplan, D. Rittel, Mater. Sci. Eng. A 597 (2013) 1.

[14] S.-T. Oh, T. Sekino, K. Niihara, J. Eur. Ceram. Soc. 18, 1 (1998) 31.

[15] K. Jach, K. Pietrzak, A. Wajler, A. Strojny-Nedza, Powder Metall. Met. Ceram. 52, 11 (2014) 680.

[16] L. Wang, J.-L. Shi, M.-T. Lin, H.-R. Chen, D.-S. Yan, Mater. Res. Bull. 36, 5-6 (2001) 925.

[17] A.K. Dutta, N. Narasaiah, A.B. Chattopadhyaya, K.K. Ray, Ceram. Int. 27 (2001) 407.

[18] A.K. Dutta, J. Mater. Sci. Lett. 20 (2001) 917.

[19] A. Mocellin, E. Mines, P. De Saurupt, N. Cedex, J. Eur. Ceram. Soc. 18 (1998) 1743.

[20] B.-T. Lee, K.-H. Kim, A.H.M.E. Rahman, H.-Y. Song, Mater. Trans. 49, 6 (2008) 1451.

[21] J.S. Lu, L. Gao, J. Sun, L.H. Gui, J.K. Guo, Mater. Sci. Eng. A. 293, 1-2 (2000) 223.

[22] A.G. Evans, E.A. Charles, J. Am. Ceram. Soc. 59, 7-8 (1976) 371.

[23] J.B. Wachtman, W.R. Cannon, M.J. Matthewson, Mechanical properties of ceramics, $2^{\text {nd }}$ Ed., John Wiley 
Sons, NJ, EUA (2009).

[24] J. Baseri, R. Naghizadeh, H.R. Rezaie, J. Ceram. Process. Res. 18, 1 (2017) 21.

[25] M.R. Movaghar Garabagh, S. Hossein Nejad, H. Shirazi, M. Iranpour Mobarekeh, M. Nili Ahmadabadi, Thin Solid Films 516 (2008) 8117.

[26] M. Tokita, in: Handbook of advanced ceramics, $2^{\text {nd }}$ Ed.,
Elsevier (2013) 1149.

[27] G.R. Anstis, P. Chantikol, B.R. Lawn, D.B.A. Marshall, J. Am. Ceram. Soc. 64, 9 (1981) 533.

[28] B.D. Cullity, Elements of X-ray diffraction, $2^{\text {nd }}$ Ed., Addison-Wesley, Reading, (1978) 281.

(Rec. 05/10/2017, Rev. 20/01/2018, 18/02/2018, Ac. 20/02/2018) 